\title{
Mitsaqan Ghalidza di Era Disrupsi (Studi Perceraian Sebab Media Sosial)
}

\author{
M. Saeful Amri* \\ Universitas Islam Negeri (UIN) Sunan Kalijaga Yogyakarta \\ Email: m.saeful.amri.sa@gmail.com
}

\begin{abstract}
This article discusses the Miśaqan Ġaliza as the principle of marriage in Islam, which in the modern era of its sacredness is fading, disrupted or even unknown to each couple. So that many marriages are carried out according to Islamic law but the essence of the teachings is abandoned. As a result, the divorce rate continues to increase among Muslim families in Indonesia and one of the triggers for the divorce is due to social media. This type of research is descriptive-analytic that is describing the facts of divorce that are happening now (Era of disruption) among Muslim families in Indonesia, then analyzed why this phenomenon can occur in terms of the Miṡaqan Galiza perspective as the principle of marriage in Islam. The results of this study conclude that the high divorce rate because of infidelity on social media is due to several things. First, cultural shifts that are increasingly open; Second, decreasing the meaning and value of marriage and Third, lack of understanding of religion.
\end{abstract}

Keywords : Mitsaqan Ghalidza, Era of Disruption, Divorce.

\begin{abstract}
Abstrak
Mitsaqan Ghalidza sebagai asas perkawinan dalam Islam di era modern kesakralannya memudar, terdisrupsi atau bahkan tidak diketahui sama sekali oleh masing-masing pasangan suami istri. Sehingga banyak pernikahan yang dilaksanakan sesuai syariat Islam namun esensi ajarannya ditinggalkan. Akibatnya angka perceraian terus meningkat dikalangan keluarga muslim di Indonesia dan salah satu pemicu sebab terjadinya perceraian tersebut adalah karena media sosial. Jenis
\end{abstract}

* Mahasiswa Pascasarjana Program Studi Syariah FSH UIN Sunan Kalijaga Yogyakarta.

Vol. 3, No. 1, Oktober 2019, 89-106 
penelitian ini adalah deskriptif-analitik yakni mendeskripsikan faktafakta perceraian yang terjadi saat ini (Era disrupsi) dikalangan keluarga muslim di Indonesia, kemudian dianalisis mengapa fenomena ini bisa terjadi ditinjau dari perspektif Mitsaqan Ghalidza sebagai asas perkawinan dalam Islam. Hasil kajian ini menyimpulkan bahwa tingginya angka perceraian sebab perselingkuhan di media sosial adalah karena beberapa hal; Pertama, pergeseran budaya yang semakin terbuka; Kedua, menurunnya makna dan nilai perkawinan dan Ketiga, minimnya pemahaman agama.

Kata Kunci : Mitsaqan Ghalidza, Era Disrupsi, Perceraian.

\section{Pendahuluan}

$\mathcal{P}$ erkawinan merupakan sesuatu yang dipandang sangat penting dalam Islam. ${ }^{1}$ Ia didefinisikan sebagai ikatan lahir dan batin (Mitsaqan Ghalidza) antara seorang lelaki dan seorang perempuan untuk hidup bersama selama-lamanya. Namun realitanya, fenomena perceraian dewasa ini semakin mewabah di kalangan keluarga muslim Indonesia. Angka perceraian meningkat dalam beberapa tahun terakhir di sejumlah daerah, dan bahkan di tingkat nasional angka cerai gugat jauh lebih tinggi dibanding angka cerai talak. ${ }^{2}$ Fenomena tersebut sangat menghawatirkan pemerintah, lantaran mengindikasikan rapuhnya lembaga perkawinan saat ini. ${ }^{3}$

Badan Pusat Statistik (BPS) meluncurkan data perceraian sepanjang kurun waktu 2010-2015 menyebutkan bahwa jumlah perceraian di Indonesia meningkat $15-20$ persen, dari gugatan cerai sebanyak 285.184 pada tahun 2010 menjadi 347.256 pada

${ }^{1}$ Q.S, Adz-Dzariyat: 49, Q.S, Yaasin: 36, Q.S, Al-Hujarat/49: 13, Q.S, An-Nisa: 1, Q.S, An-Nahl: 72, Kemenag, Al-Qur'an dan Terjemahnya, (Jakarta: Unit Percetakan Al-Qur'an, 2017)

2 Data: Litbang Merdeka.com, Noktah Merah Perkawinan di Indonesia, 2016.

3 Merdeka.com (20 september 2016) Indonesia darurat perceraian, (online), Available: https://www.merdeka.com/khas/indonesia-daruratperceraian-tren-perceraian-meningkat-1. Diakses pada hari minggu, 10/11/2019 pukul 08:26 WIB.

Ulul Albab: Jurnal Studi dan Penelitian Hukum Islam 
tahun $2015,{ }^{4}$ artinya dalam hitungan jam (setiap satu jam) ada sekitar empat puluh sidang perceraian yang diputus oleh peradilan agama se-Indonesia. Menurut Dr. Sudibyo Alimoeso, Deputi Keluarga Sejahtera dan Pemberdayaan Keluarga BKKBN, data-data tesebut telah menempatkan Indonesia sebagai negara dengan tingkat perceraian tertinggi se Asia Pasifik. ${ }^{5}$

Berdasarkan penelitian Kustini dan Ida Rashidah, dalam buku "Tren Cerai Gugat: Ketika wanita bersikap" menjelaskan bahwa fenomena tingginya angka perceraian sebagaimana tersebut di atas terjadi karena beberapa hal; Pertama, lantaran adanya pergeseran budaya yang semakin terbuka. Kedua, menurunnya makna dan nilai perkawinan. Dan ketiga karena lemahnya pemahaman agama. ${ }^{6}$

Pergeseran budaya disebabkan oleh revolusi industri 4.0 berdampak pada perkawinan. Tidak pelak lagi pergeseran itu merenggut makna dan nilai perkawinan yang suci, seingga seolah perkawinan hanya untuk menghalalkan perilaku seksual antara laki-laki dan perempuan semata daripada berfikir tanggung jawab. ${ }^{7}$ Persoalan ini bertambah kompleks tatkala merosotnya tingkat pemahaman umat Islam terhadap pemahaman agama, khususnya asas perkawinan yang disebut Mitsaqan Ghalidza.

Dari problematika yang penulis paparkan di atas, beberapa permasalahan yang diketengahkan artikel ini antara lain tentang penyebab terjadi penurunan makna dan nilai perkawinan. Selain itu, artikel ini juga membahas permasalahan konsep

${ }^{4}$ Badan Pusat Statistika (BPS), Nikah, talak dan cerai, serta rujuk, 2012-2015.

${ }^{5}$ Kompasiana (Desember 31, 2015) catatan akhir 2015: Perceraian masih terus menigkat. (online). Available: https://www.kompasiana.com/pakcah/catatan-akhir2015-perceraian-masih-terus meningkat. diakses pada hari minggu, 10/11/2019 pukul 09:06 WIB.

${ }^{6}$ Kustini dan Ida Rasidah, Ketika Perempuan Bersikap: Tren Cerai Gugat Masyarakat Muslim, (Jakarta: Puslitbang Kehidupan Keagamaan, 2016), ix

7 Elizabeth Diana Dewi, "Bias Paham Feminisme Barat". Journal Islamia, Vol. III No. 5, 2010, 85. 
92 M. Saeful Amri

Mitsaqan Ghalidza yang dijadikan asas perkawinan dalam menghadapi berbagi macam pergeseran tersebut.

\section{Metode Penelitian}

Jenis penelitian yang digunakan dalam artikel ini adalah library research (penelitian pustaka) yaitu penelitian yang menggunakan buku-buku sebagai sumbernya. ${ }^{8}$ Sifat penelitian ini adalah deskriptif-analitik yakni mendeskripsikan fakta-fakta perceraian yang terjadi saat ini (Era disrupsi) di kalangan keluarga muslim di Indonesia. Kemudian dilakukan analisis terkait fenomena perceraian di era disrupsi dengan menggunakan perspektif mitsaqan ghalidza sebagai asas perkawinan dalam Islam.

Penelitian ini menggunakan pengumpulan data dengan metode dokumentasi. Dokumentasi terkait dengan data perceraian dan sumber literasi. Data primer dalam penelitian ini adalah data perceraian akses dari Direktorat Jenderal Badan Peradilan Agama (Badilag) tahun 2015, Badan Peradilan Agama MA RI tahun 2014, Badan Pusat Statistika (BPS) tahun 2010-2015. beberapa hasil penelitian. Sedangkan data sekundernya adalah data yang penulis peroleh dari buku-buku, artikel, internet dan pendapat para ahli yang relevan dengan isu yang sedang penulis teliti.

\section{Mitsaqan Ghalidza dalam Perspektif Islam}

Pernikahan merupakan perjanjian suci yang diucapkan oleh dua jenis manusia, yaitu laki-laki dan perempuan untuk membangun rumah tangga. Perjanjian tersebut tidak saja sakral, suci, dan luhur namun mengandung komitmen Ilāhi. Disebutkan dalam Q.S, Al-Nisā': 21: “Dan bagaimana kamu akan mengambilnya kembali, padahal kamu telah bergaul satu sama lain (sebagai suami istri). Dan mereka (istri-istrimu) telah mengambil

${ }^{8}$ Sutrisno, Metodologi Research, (Yogyakarta: LkiS, 1990), 9. 
perjanjian yang kuat (ikatan pernikahan) dari kamu". 9 Dari sini akan dijelaskan beberapa tafsiran tentang kalimat Mitsaqan Ghalidza.

Dalam Kompilasi Hukum Islam (KHI) perkawinan didefinisikan sebagai pernikahan yaitu akad yang sangat kuat atau Mitsaqan Ghalidza untuk mentaati perintah Allah dan melaksanakannya merupakan ibadah (pasal 2). Tujuaannya ialah untuk mewujudkan kehidupan rumah tangga yang sakinah, mawaddah, dan rahmāt (pasal 3). Dan perkawinan adalah sah apabila dilakukan menurut hukum Islam sesuai dengan pasal 2 ayat (1) Undang-undang No. 1 Tahun 1974 tentang Perkawinan (Pasal 4). ${ }^{10}$

Ahmad Fa'iz dalam buku "Cita Keluarga Islam: Pendekatan Tafsir Tematik" menjelaskan bahwa kata Afdhā makna harfiahnya adalah "meluapkan" tanpa objek tertentu. Ia berdiri bebas dan pengertiannya tidak terbatas pada makna fisik saja, tapi juga meliputi makna-makna batini seperti emosi, jiwa, persepsi, rahasia dan impian, serta hubungan timbal balik antara dua pihak dalam segala bentuknya. Kata tersebut dibiarkan untuk mencurahkan berpuluh ilustrasi tantang kehidupan suami istri sepanjang siang dan malam, berpuluh pengalaman yang pernah terjadi selama lembaga rumah tangga itu bendiri. Gambaran-gambaran tersebut kemudian dipadukan dengan ilustrasi dan corak lain dari kehidupan suami istri yang pernah ada: "Dan mereka (istri-istrimu) telah mengambil darimu perjanjian yang kuat." Yakni perjanjian yang kuat atas nama Allah dan sunnah Rasulnya. Al-Qur'an mengingatkan mereka agar menghormati perjanjian ini. ${ }^{11}$

Menurut Imam al-Tabari dalam tafsirnya menjelaskan bahwa Mitsaqan Ghalidza bisa diungkapkan dalam berbagai

${ }^{9}$ Kemenag, Al-Qur'an dan Terjemahnya... h. xii.

${ }^{10}$ Kemenag, Kompilasi Hukum Islam di Indonesia, (Jakarta: Direktorat Bina KUA dan Keluarga Sakinah, 2018), 5.

${ }^{11}$ Ahmad Fa'iz, Cita Keluarga Islam: Pendekatan Tafsir Tematik, (terj) Cet. VI, (Beirut: Mu'assasah al-Risalah, 1992) h. 177-178. 
94 M. Saeful Amri

redaksi namun tetap bermakna suatu perjanjian yang kuat dan kokoh, di antaranya: 1) wali berkata, Ankahnakaha biamanatillah (saya nikahkan engkau dengan amanah Allah). 2) kalimat "nikah" yang menghalalkan farajnya dengan kalimah Allah. 3) Nakahtu (saya menikahinya). 4) Malaktu (saya memilikinya). 5) al-Misāa yang sama dengan al-Nikah. 6) Mitsaqan Ghalidza yaitu Imsak bi al-ma'rūf au tașrih bi al-iḥsan (perjanjian yang kuat, dimaksudkan kalian menahannya atau memperlakukannya dengan makruf dan menceraikan dengan baik). ${ }^{12}$

Sedang menurut Quraish Shihab, tafsiran kalimat Mitsaqan Ghalidza adalah keyakinan yang dituangkan istri kepada suaminya dan dianggap bahwa perkawinan itu sebagai sebuah amanah. Sebagaimana hadis Nabi yang redaksinya menyatakan: akhadztumuhunna biamanatillah (kalian menerima istri berdasarkan amanah Allah). Karena itu kesediaan seorang istri yang hidup bersama dengan seorang lelaki, meninggalkan orang tua dan keluarga yang membesarkannya, dan mengganti semua itu dengan penuh kerelaan untuk hidup bersama lelaki "asing" yang menjadi suaminya, serta membuka "rahasianya yang paling dalam", merupakan hal yang sungguh mustahil, kecuali ia merasa yakin bahwa kebahagiaannya bersama suami akan lebih besar dibanding dengan kebahagiaannya bersama ibu dan bapak, dan pembelaan suami terhadapnya tidak lebih sedikit dari pembelaan saudara-saudara sekandungnya. Keyakinan yang dituangkan istri kepada suaminya itulah yang dimaksud Al-Qur'an sebagai Mitsaqan Ghalidza (perjanjian yang amat kokoh). ${ }^{13}$

Jadi pernikahan itu mengandung suatu perjanjian yang kokoh dan kuat, karena diterima sebagai amanah Allah, kemudian menghalalkan hubungan seksualnya dengan kalimatullah. Apabila dikemudian hari terjadi perselingkuhan

${ }^{12}$ At-Tabari, Tafsir at-Tabari, t.t: t.p, t.th, Jilid IV, h. 352.

${ }^{13}$ M. Quraish Shihab, Wawasan Al-Qur'an: Tafsir Tematik atas Pelbagai Persoalan Umat, (Bandung: Penerbit Mizan, 2007), 287.

Ulul Albab: Jurnal Studi dan Penelitian Hukum Islam 
diantara suami dan istri maka pertanggungjawaban keduanya tidak hanya pada masing-masing pasangan melainkan juga kepada Allah. Sebab pengkhianatan terhadap pasangan dalam perkawinan merupakan pengkhianatan kepada Allah. Maka dari itu Allah menyebutkan dalam surat al-Nisā'ayat 34 bahwa ciri istri salehah atau ciri dari suami yang saleh ialah yang mampu menjaga diri ketika pasangannya tidak ada (hafizat li algaib). Sebab menjaga diri dengan baik ketika berjauhan dari istri atau suami adalah bentuk pertanggung jawaban kepada Allah.

\section{Era Disrupsi: Potret Menurunnya Nilai dan Makna Perkawinan}

Disrupsi adalah kosakata baru yang berasal dari bahasa Inggris "disruption" yang dalam Kamus Besar Bahasa Indonesia (KBBI) diartikan sebagai "hal tercabut dari akarnya". ${ }^{14}$ Istilah ini pertama kali dipopulerkan oleh Clayton M. Christensen, professor Administrasi Bisnis dari Universitas Harvard. Christensen menyebut disrupsi sebagai sebuah perubahan besar yang membuat industri tidak berjalan seperti biasa, umumnya karena penemuan teknologi. ${ }^{15}$

Rhenald Kasali dalam bukunya berjudul "Disruption" menjelaskan bahwa perubahan yang terjadi diawali dengan hal yang kecil, sehingga terabaikan oleh mereka yang besar. Perubahan itu bahkan tidak terlihat, dan tiba-tiba tumbuh begitu besar. ${ }^{16}$ Inilah karakter perubahan pada abad ke-21: Cepat, mengejutkan, memindahkan. Akibatnya apapun disrupsi yang terjadi selalu akan menciptakan peluang sekaligus ancaman bagi

14 Kamus Besar Bahasa Indonesia (versi online), https://www.kbbi.web.id/disrupsi, diakses pada hari minggu, 03/11/2019, pukul 03.17 WIB.

${ }^{15}$ Majalah iMAGZ, Disruption Era, edisi april-juni, PT Asuransi Tugu Pratama IndonesiaTbk, 2018, 6.

16 Rhenald Kasali, Disruption: Tak ada yang tak bisa diubah sebelum dihadapi motivasi saja tidak cukup, ( Jakarta: PT Gramedia Pustaka Utama, 2017), xi. 
siapapun, karena dunia telah berubah dari berbagai sisi yang dipengaruhi oleh revolusi industry 4.0, generasi manusia baru, dan kebutuhan akan kecepatan yang luar biasa.

Manusia tidak hanya bersaing dengan manusia lainnya tetapi juga pada mesin-mesin dan robot-robot yang memiliki tingkat efisiensi yang jauh lebih tinggi. Hal tersebut merupakan sebuah tantangan dan sekaligus kenyataan yang tidak bisa dipungkiri. Evolusi dibidang teknologi dan inovasi internet tidak hanya memunculkan media baru saja tetapi juga merubah berbagai macam aspek kehidupan manusia seperti komunikasi dan interakasi. Jika dahulu perkenalan dilakukan dengan cara kovensional, yakni biasanya diiringi dengan saling tukar kartu nama, sekarang berbeda, bukan lagi tukar kartu nama tetapi tukar alamat akun atau membuat pertemanan di media sosial. ${ }^{17}$

Media sosial adalah sebuah media online dengan para penggunanya dapat dengan mudah berpartisipasi, berbagi, dan menciptakan isi meliputi blog, jejaring sosial dan wiki merupakan bentuk media sosial yang paling umum digunakan oleh masyarakat di seluruh dunia. Pendapat lain mengatakan bahwa media sosial adalah media online yang mendukung interaksi sosial dan media sosial menggunakan media berbasis web seperti facebook, twitter, instagram, whatsapp dan sebagainya yang mengubah komunikasi menjadi dialog interaktif. ${ }^{18}$ Dengan adanya media sosial tersebut banyak orang dimudahkan untuk mendapatkan teman baru, dan dari perkenalan tersebut, tidak sedikit yang sukses hingga menuju pelaminan. Inilah kemudahan yang dirasakan di era modern saat ini.

17 Mulawaraman, Aldila Dyas Nurfitri, “Perilaku penggua media sosial beserta implikasinya ditinjau dari perspekif psikologi sosial terapan, Buletin Psikologi, Vol. 25 No. 1, 2017, 36.

18 Anang Sugeng Cahyono, Pengaruh media sosial terhadap perubahan sosial masyarakat di Indonesia, h. 142 diakses pada rabu, 13/11/2019 pukul 10.03 WIB. http://www.jurnal-unita.org/index.php/publiciana/article/viewFile/79/73

Ulul Albab: Jurnal Studi dan Penelitian Hukum Islam 
Namun pada kenyataannya, terjadi kecenderungan yang sangat memprihatinkan di kalangan masyarakat modern. Bersamaan dengan berkembangnya ilmu pengetahuan, banyak kaum perempuan yang memiliki kesempatan berpendidikan tinggi, sejajar dengan kaum laki-laki. Bahkan lahir pula gerakangerakan emansipasi yang menuntut kesetaraan antara laki-laki dan perempuan dalam segala bidang. Kondisi ini melahirkan kaum perempuan yang menempati posisi karir yang tinggi, bahkan sering kali lebih tinggi dari laki-laki. Dalam posisi seperti itu, fungsi ekonomi dan perlindungan bagi seorang perempuan yang sudah menikah menjadi kabur. Masyarakat modern cenderung berfikir dan bersikap pragmatis, sehingga pernikahan lebih diutamakan sebagai fungsi seksual, reproduksi dan rekreasi. Akibatnya, rumah tangga tidak lebih dari sekedar "tempat bermalam dan melakukan kegiatan seksual". ${ }^{19}$

Bahkan selanjutnya, mereka sudah tidak lagi perduli, apakah untuk keperluan tersebut masih diperlukan pernikahan formal atau tidak. Sehingga hubungan interaksi yang dibangun bukan lagi bertujuan untuk saling menjaga satu sama lain melainkan untuk sama-sama mendapatkan kesenangan sesaat. Akibatnya banyak perceraian yang terjadi karena sebab perselingkuhan di media sosial dan tentu saja fenomena ini sangat menghawatirkan masyarakat Indonesia, sebab hal ini menyangkut kestabilan Negara. Karena menurut Syamsuddin Arif utuhnya suatu Negara terkait erat pada ketahanan keluarga, dan runtuhnya suatu bangsa barawal dari runtuhnya keluarga, semakin rentan dan rapuh institusi keluarga disuatu Negara maka akan berdampak pada stabilitas Negara tersebut. ${ }^{20}$

19 Anshari Thayib, Struktur Rumah Tangga Islam, Risalah Gusti: T.t.,T.t.,h. 3 .

${ }^{20}$ Syamsuddin Arif, Islam dan Diabolisme Intelektual, INSIST, 2017. h, 175 . 
98 M. Saeful Amri

\section{Perceraian dan Media Sosial}

Perceraian bukanlah fenomena baru di kalangan keluarga muslim di Indonesia. Data di Badan Peradilan Agama (pusat) maupun Peradilan Agama (kabupaten/kota) menunjukkan kenaikan angka perceraian dari tahun ke tahun. Dan selama beberapa dekade angka cerai gugat lebih dominan dibanding cerai talak. Merujuk pada data Direktorat Jenderal Badan Peradilan Agama (Badilag) tahun 2015, angka cerai gugat mencapai $72 \%$ disbanding cerai talak yang mencapai $28 \%$.

Tabel 1

Jumlah Perkara Yang diputus PA / MS se Indonesia

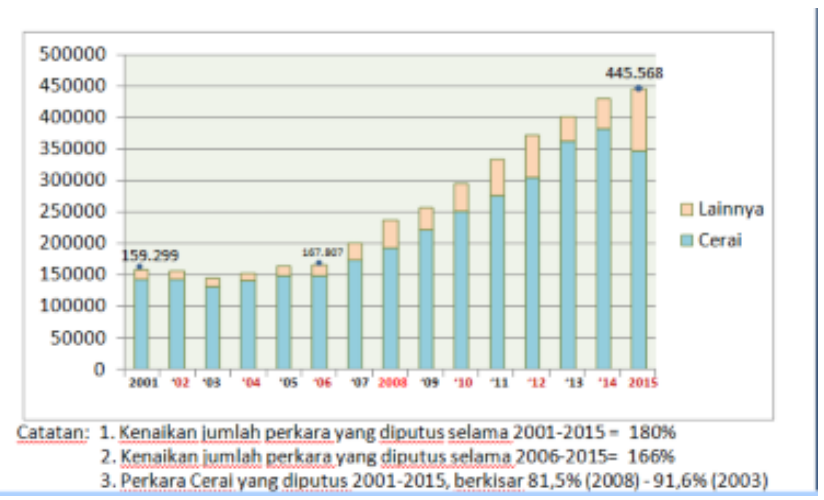

Jika kita perhatikan data yang diputus Pengadilan Agama/Mahkamah Syar'iyah (PA/MS) untuk semua jenis perkara secara nasional selama periode 2001-2015, ada kenaikan sebesar $180 \%$, yaitu dari 159.299 perkara pada tahun 2001 menjadi 445.568 perkara pada tahun 2015. Kenaikan tajam terjadi di tahun 2006, yaitu sejak jumlah perkara yang diputus 167.807 perkara. Pada tahun 2001-2006 kenaikannya hanya 5\%. Sedangkan pada periode 2006-2015 kenaikannya mencapai $166 \%$.

Data pada tahun 2010-2014 menunjukkan bahwa dari sekitar dua juta pasangan yang menikah, ada 15\% atau sekitar tiga ratus ribu pasangan yang melakukan perceraian di 
Pengadilan Agama/Mahkamah Syar'iyah. ${ }^{21}$ Adapaun data perceraian yang diputus Pengadilan Agama/Mahkamah Syar'iyah seluruh Indonesia selama lima tahun berturut-turut adalah sebagai berikut:

Tabel 2

Angka Perceraian 2010-2014

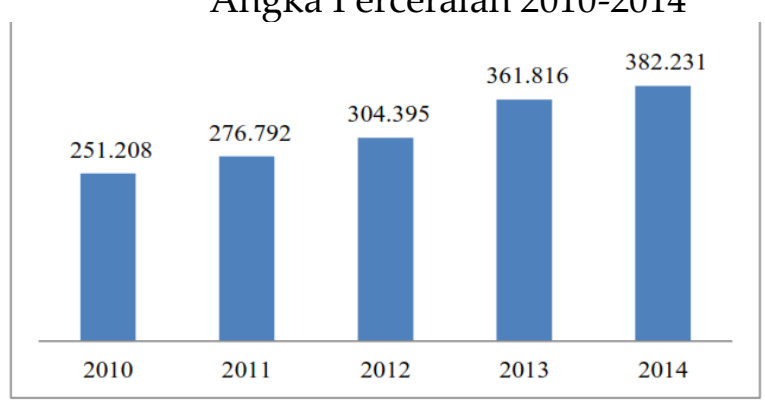

Sumber: Badan Peradilan Agama MA RI, 2014

Angka perceraian selama lima tahun berturut-turut yakni pada tahun 2010-2015 selalu meningkat. Dari 251.208 perkara pada 2010 menjadi 382.231 perkara pada 2015, naik sekitar 15 persen. Sedangkan Badan Pusat Statistik (BPS) meluncurkan data perceraian sepanjang kurun waktu 2010-2015 menyebutkan bahwa jumlah perceraian di Indonesia meningkat 15-20 persen, dari gugatan cerai sebanyak 285.184 pada tahun 2010 menjadi 347.256 pada tahun $2015,{ }^{22}$ berarti ada sekitar 40 perceraian yang terjadi di Indonesia dalam setiap jam. Menurut Dr. Sudibyo data-data tesebut telah menempatkan Indonesia sebagai negara dengan tingkat perceraian tertinggi se Asia Pasifik. ${ }^{23}$

\footnotetext{
${ }^{21}$ Kustini dan Ida Rasidah, Ketika Perempuan Bersikap...., h. 1.

${ }^{22}$ Badan Pusat Statistika (BPS), Nikah, talak dan cerai, serta rujuk, 20122015.

${ }^{23}$ Kompasiana (Desember 31, 2015) catatan akhir 2015: Perceraian masih terus meningkat. (online). Available: https://www.kompasiana.com/pakcah/catatan-akhir-2015-perceraian-masihterus-meningkat Diakses pada hari minggu, 10/11/2019 pukul 08:26 WIB.
} 
$100 \mid$ M. Saeful Amri

Adapun perceraian tersebut dilakukan oleh suami maupun istri dengan berbagai alasan. Sebagaimana yang disebutkan dari data perceraian yang ada di Badan Peradilan Agama (Badilag) Mahkamah Agung (MA) RI, bahwa ada tiga alasan utama yang menyebabkan terjadinya perceraian; Pertama, Karena sebab ketidakharmonisan. Kedua, Karena faktor ekonomi, dan Keiga, Karena faktor gangguan orang ketiga baik dari pihak keluarga ataupun perselingkuhan di media sosial.

Tabel 3

Alasan Perceraian 2010-2014

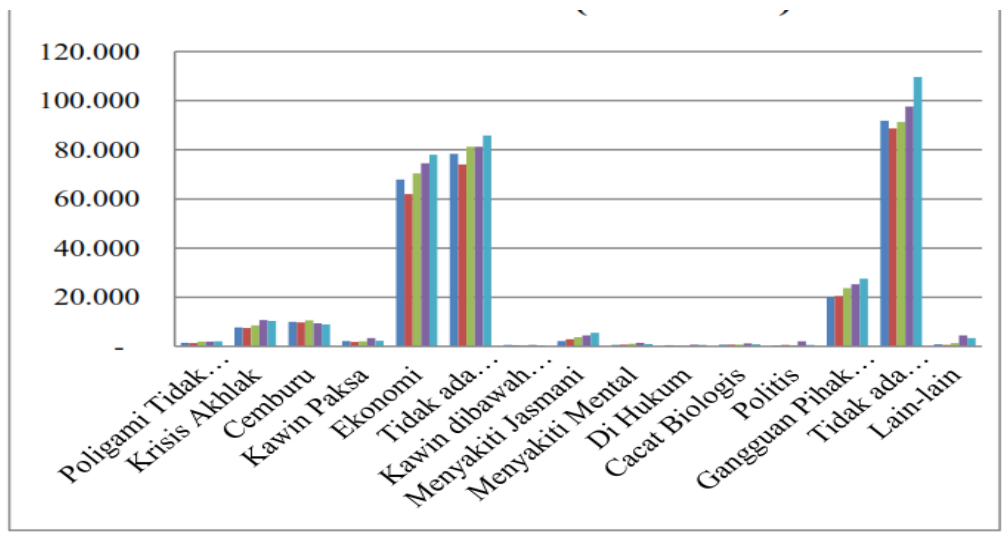

Sumber: Badan Peradilan Agama MA RI 2014

Dari gambar tabel diatas (Tabel 3) ${ }^{24}$ faktor perceraian karena gangguan pihak ketiga karena pihak keluarga atau perselingkuhan menempati posisi ketiga setelah faktor ekonomi dan faktor ketidakharmonisan. Faktor gangguan pihak ketiga ini ditengarai lebih banyak merupakan persoalan gaya hidup. Fenomena ini tidak hanya terjadi di kota, tetapi juga sudah merambah kewilayah pedesaaan, tidak hanya terjadi pada pasangan usia muda, tetapi juga pasangan-pasangan yang sudah cukup lama menikah. Pada persoalan ini, sangat mungkin dipengaruhi oleh dampak hadirnya media komunikasi, baik

${ }^{24}$ Kustini dan Ida Rasidah, Ketika Perempuan Bersikap...., 2.

Ulul Albab: Jurnal Studi dan Penelitian Hukum Islam 
televisi, telepon seluler, dan media sosial. Berbagai sarana komunikasi tersebut menyebabkan komunikasi individu dengan individu lain semakin lebih mudah.

Data perceraian di pengadilan agama kota bekasi misalnya adalah sebanyak 2231 pasangan pada tahun 2017. Faktor pemicu terbanyak adalah karena faktor perselingkuhan yakni sebanyak 1862 kasus, karena faktor ekonomi adalah sebanyak 111 kasus, dan faktor poligami sebanyak 121 kasus. Dari banyak kasus perceraian tersebut pemicu utama dimulai dari media sosial. Beberapa pasangan suami istri menyelasaikan permasalahan rumah tangga, yang seharusnya dibicarakan secara langsung justru dilakukan melalui media sosial dan berakhir dengan perceraian yang mengorbankan anak mereka. ${ }^{25}$ Hal seperti ini tidak hanya terjadi dikota bekasi tetapi juga di daerah lain melalui putusan hakim yang dicontohkan dalam beberapa hasil penelitian.

Pertama, di Yogyakarta, Muhammad Luthfi Hakim, mahasiswa fakultas syariah dan hukum universitas Islam negeri sunan kalijaga, menulis skripsi berjudul "Perselingkuhan Melalui Jejaring Sosial Whatsapp Sebagai Alasan Perceraian (Studi Terhadap Putusan di Pengadilan Agama Yogyakarta No. 0121/Pdt.G/2017/PA.YK)". Skripsi tersebut menjelaskan perselingkuhan yang dilakukan oleh penggugat dan tergugat serta dasar hukum apa yang digunakan oleh majelis hakim dalam menetapkan keputusan tersebut, mengingat belum adanya peraturan perundangan-undnagan yang jelas yang mengatur tentang perselingkuhan melalui jejraring sosial whatsapp. ${ }^{26}$

25 Youtube: Jaktv Official Channel, Media sosial penyebab perceraian, diakses pada 11 November 2019 pukul 20.21 WIB.

${ }^{26}$ Muhammad Luthfi Hakim, (Skripsi) Perselingkuhan Melalui Jejaring Sosial Whatsapp Sebagai Alasan Perceraian (Studi Terhadap Putusan di Pengadilan Agama Yogyakarta No. 0121/Pdt.G/2017/PA.YK) diakses pada hari rabu, 13 
Kedua, di Medan Sumatera Utara, Siti Hajar, mahasiswi fakultas hukum universitas sumatera utara, menulis skrip berjudul "Gugatan Perceraian Dikarenakan Perselingkuhan Di Media Sosial Menurut Hukum Islam (Studi Putusan: 1979/Pdt.G/2017/PA.Mdn). Menurutnya, Perceraian karena perselingkuhan melalui media sosial seperti Sms, Facebook, Chat (BBM, YM, Skype, dan Whatsapp) adalah sah dan diqiyaskan kepada talak dengan tulisan karena keduanya merupakan pesan cerai melalui teks yang bukan verbal (lisan). Para ulama fikih sepakat bahwa hal tersebut efektif jatuh talak karena tulisan dinilai sama dengan ucapan. ${ }^{27}$

Putusan para hakim tersebut di atas mengindikasikan bahwa media sosial tidak dapat dijadikan sebagai alasan perceraian di Pengadilan Agama, melainkan sebagai pemicu lahirnya konflik dan ketidakharmonisan secara terus menerus antara pasangan suami istri hingga akhirnya berakhir di meja sidang pengadilan agama. Pertimbangan hakim dalam memutuskan perkara gugatan perceraian adalah karena perselingkuhan dengan alasan-alasan yang dapat dipertanggungjawabkan yaitu sebagaimana yang telah ditentukan di dalam penjelasan undang-undang no 1 tahun 1974 pasal 39 ayat (2) dan PP No. 9 Tahun 1975 pasal 19 serta KHI pasal 116.

Adapun hak dan kedudukan anak setelah perceraian karena perselingkuhan di media sosial adalah hadhanah, yaitu hak yang berkaitan dengan seorang anak yang masih kecil baik anak laki-laki ataupun perempuan karena ia masih sangat

\footnotetext{
November 2019 pukul 20:15 WIB. http://digilib.uinsuka.ac.id/34575/1/14350018_BAB-I_BAB-V_DAFTAR-PUSTAKA.pdf

${ }^{27}$ Siti Hajar, (Skripsi) Gugatan Perceraian Dikarenakan Perselingkuhan Di Media Sosial Menurut Hukum Islam (Studi Putusan:1979/Pdt.G/2017/PA.Mdn), diakses pada hari rabu, 13 November 2019 pukul 21:34 WIB http://repositori.usu.ac.id/bitstream/handle/123456789/11112/140200142.pdf?s equence $=1$ \&isAllowed $=y$
}

Ulul Albab: Jurnal Studi dan Penelitian Hukum Islam 
membutuhkan perawatan, pemeliharaan, penjagaan, kasih sayang, perlindungan dan pendidikan agar ia dapat membedakan perilaku baik dan buruk, menjadi manusia yang hidup sempurna serta bertanggung jawab di masa depannya. ${ }^{28}$

Menurut hemat penulis langkah preventif yang dapat dilakukan untuk meminimalisir fenomena tersebut adalah dengan memperdalam ilmu agama agar pasangan suami istri memahami asas-asas perkawinan dalam Islam sekaligus menerapkannya dalam hubungan perkawinan. Sebagaimana disampaikan oleh Ahmad Hatt dkk, ketika mendeskripsikan kehidupan rumah tangga yang sakinah, mawaddah, warahmāt ibarat sebuah rumah; Fondasinya adalah ketakwaan suami dan istri (At-Tahrim (66): 6), pilarnya adalah kepemimpinan (qawwāmah) suami, dindingnya adalah keshalihan istri (șāliḥ̂ah), jendelanya adalah ketaatan istri kepada suami (qanitāt), pintunya adalah kemampuan istri untuk menjaga diri dan keluarganya (hafizhat) An-Nisa: 34, dan atapnya adalah pergaulan yang baik antara suami dan istri (al-mu'asharah bi al$\left.m a^{\prime} r u \bar{f}\right)$ An-Nisa: $19 .{ }^{29}$

\section{Kesimpulan}

Terjadinya penurunan makna dan nilai perkawinan adalah dampak dari berkembanya revolusi industry 4.0 dimana Masyarakat modern cenderung berfikir dan bersikap pragmatis, sehingga pernikahan lebih diutamakan sebagai fungsi seksual, reproduksi dan rekreasi. Akibatnya, rumah tangga tidak lebih dari sekedar "tempat bermalam dan melakukan kegiatan seksual".

Hasilnya adalah tingginya angka perceraian sebab perselingkuhan melalui media sosial dikalangan keluarga

${ }^{28}$ Siti Hajar, (Skripsi) Gugatan Perceraian ....

${ }^{29}$ Ahmad Hatt dkk, Bimbingan Islam untuk hidup Muslim: petunjuk praktis menjadi muslim seutuhnya dari lahir sampai mati berdasarkan al-Qur'an dan As-Sunnah, (Jakarta: Maghfirah Pustaka, 2014), 290. 
$104 \mid$ M. Saeful Amri

muslim di Indonesia. Perselingkuhan tersebut terjadi bukan saja sebab media sosial tetapi juga lantaran merosotnya tingkat pemahaman umat Islam terhadap pemahaman agama, khususnya asas perkawinan yang disebut Mitsaqan Ghalidza.

Mitsaqan Ghalidza adalah suatu perjanjian yang kokoh dan kuat, karena diterima sebagai amanah Allah, kemudian menghalalkan hubungan seksualnya dengan kalimatullah. Apabila dikemudian hari terjadi perselingkuhan diantara suami dan istri maka pertanggungjawaban keduanya tidak hanya pada masing-masing pasangan melainkan juga kepada Allah. Sebab pengkhianatan terhadap pasangan dalam perkawinan merupakan pengkhianatan kepada Allah.

\section{Daftar Pustaka}

Ali, Ahmad. 2009. Menguak Teori Hukum (Legal Theory) dan Teori Peradilan (Judicial Prudence) termasuk Interpretasi UndangUndang (Legal Prudence). Jakarta: Penerbit kencana Jakarta.

Al-Qur'an dan Terjemahnya. 2017. Jakarta: Unit Percetakan AlQur'an

At-Tabari. Tafsir at-Tabari. t.t: t.p, t.th, Jilid IV.

Fa'iz, Ahmad. 1992. Cita Keluarga Islam: Pendekatan Tafsir Tematik. (terj) Cet. VI. Beirut: Mu'assasah al-Risalah

Thayib, Anshari. Struktur Rumah Tangga Islam. Risalah Gusti

Ahmad Hatt dkk. 2014. Bimbingan Islam untuk hidup Muslim: petunjuk praktis menjadi muslim seutuhnya dari lahir sampai mati berdasarkan al-Qur'an dan As-Sunnah. Jakarta: Maghfirah Pustaka.

Badan Pusat Statistika (BPS). Nikah, talak dan cerai, serta rujuk.2012-2015.

Data: Litbang Merdeka.com. 2016. Noktah Merah Perkawinan di Indonesia.

Diana Dewi, Elizabeth. 2010. "Bias Paham Feminisme Barat". Journal Islamia. Volume III. No. 5 
Mitsaqan Ghalidza di Era Disrupsi .... $\mid 105$

Kustini dan Rasidah, Ida. 2016. Ketika Perempuan Bersikap: Tren Cerai Gugat Masyarakat Muslim. Jakarta: Puslitbang Kehidupan Keagamaan.

Kemenag. 2018. Kompilasi Hukum Islam di Indonesia. Jakarta: Direktorat Bina KUA dan Keluarga Sakinah.

Shihab, M. Quraish. 2007. Wawasan Al-Qur'an: Tafsir Tematik atas Pelbagai Persoalan Umat, Bandung: Penerbit Mizan.

Majalah Imagz. 2018. Disruption Era. eApril-Juni. PT Asuransi Tugu Pratama Indonesia Tbk.

Mulawaraman dan Nurfitri, Aldila Dyas. 2017. "Perilaku penggua media sosial beserta implikasinya ditinjau dari perspekif psikologi sosial terapan, Buletin Psikologi". Vol 25. no 1.

Kasali, Rhenald. 2017. Disruption: Tak ada yang tak bisa diubah sebelum dihadapi motivasi saja tidak cukup. Jakarta: PT Gramdeia Pustaka Utama,

Arif, Syamsuddin. 1990. Islam dan Diabolisme Intelektual, INSIST, 2017.

Sutrisno. 1990. Metodologi Research. Yogyakarta: LKiS.

Anang Sugeng Cahyono, Pengaruh media sosial terhadap perubahan sosial masyarakat di Indonesia, dikases pada rabu, 13/11/2019 pukul 10.03 WIB. http://www.jurnalunita.org/index.php/publiciana/article/viewFile/79/73

Kompasiana (Desember 31, 2015) catatan akhir 2015: Perceraian masih terus menigkat. (online). Available: https://www.kompasiana.com/pakcah/catatan-akhir2015-perceraian-masih-terus meningkat. diakses pada hari minggu, 10/11/2019 pukul 09:06 WIB.

Kamus Besar Bahasa Indonesia (versi online), https:/www.kbbi.web.id/disrupsi, diakses pada hari minggu, 03/11/2019, pukul 03.17 WIB.

Muhammad Luthfi Hakim, (Skripsi) Perselingkuhan Melalui Jejaring Sosial Whatsapp Sebagai Alasan Perceraian (Studi Terhadap Putusan di Pengadilan Agama Yogyakarta No. 
0121/Pdt.G/2017/PA.YK) diakses pada hari rabu, 13 November 2019 pukul 20:15 WIB. http://digilib.uinsuka.ac.id/34575/1/14350018_BAB-I_BAB-V_DAFTARPUSTAKA.pdf

Merdeka.com (20 september 2016) Indonesia darurat perceraian, (online), Available: https://www.merdeka.com/khas/indonesia-daruratperceraian-tren-perceraian-meningkat-1. Diakses pada hari minggu, 10/11/2019 pukul 08:26 WIB.

Siti Hajar, (Skripai) Gugatan Perceraian Dikarenakan Perselingkuhan Di Media Sosial Menurut Hukum Islam (Studi Putusan:1979/Pdt.G/2017/PA.Mdn), http://repositori.usu.ac.id/bitstream/handle/123456789/1 1112/140200142.pdf?sequence $=1 \&$ isAllowed $=y \quad$ diakses pada hari rabu, 13/11/2019 pukul 21:34 WIB

Youtube: Jaktv Official Channel, Media sosial penyebab perceraian, diakses pada 11 November 2019 pukul 20.21 WIB. 